\title{
\#USGS
}

science for a changing world

\section{Relations Between The Richmord Mountain Thrust, And The Crescent Valley-Independence Lineament, Lynn Window, Eureka County, Nevada}

by Stephen G. Peters ${ }^{1}$

Open-File Report 99-329

1999

This report is preliminary and has not been reviewed for conformity with IJ.S. Geological Survey editorial standards or with the North American Stratigraphic Code. Any use of trade, product, or firm names is for descriptive purposes only and does not imply endorsement by the U.S. Government.

\section{U.S. DEPARTMENT OF THE INTERIOR U.S. GEOLOGICAL SURVEY}

'U.S. Geological Survey, Reno Field Office, Mackay School of Mines, MS-176, University of Nevada, Renn, Nevada 89557-0047 


\section{CONTENTS}

$\begin{array}{ll}\text { Abstract } & 1\end{array}$

Introduction $\quad 2$

General Geology 2

Summary of Lynn window geology

Sedimentary rocks $\quad 5$

Igneous Rocks 6

Contact metamorphism and metasomatism $\quad 7$

$\begin{array}{ll}\text { Structure } & 7\end{array}$

$\begin{array}{ll}\text { Mineralization and Geochemistry } & 10\end{array}$

$\begin{array}{ll}\text { Discussion and Conclusions } & 10\end{array}$

Acknowledgments $\quad 13$

References Cioted 13

\section{List of Figures}

Figure 1. Generalized geology of the Carlin trend. 3

Figure 2. Stereographic projections of foliation and fold axes in the Bob's Flat quadrangle area 4

Figure 3. Relation of Richmond Mountain area to the CVIL 12

\section{List of Tables}

Table 1. Geochemical analysis of selected rock samples from the Richmond Mountain area.

\section{List of Plates}

Plate 1. Geologic map of the Richmond Mountain area, Lynn window, Eureka County, Nevada 


\title{
RELATIONS BETWEEN THE RICHMOND MOUNTAIN THRUST, AND THE CRESCENT VALLEY-INDEPENDENCE LINEAMENT, LYP ${ }^{\top} N$ WINDOW, EUREKA COUNTY, NEVADA
}

\author{
By
}

\author{
Stephen G. Peters
}

Abstract

The Richmond Mountain thrust is in the southern part of the Lynn Window of the Roberts Mountains thrust, the largest window in the Carlin trend, which exposes an Ordovician to Devonian miogeoclinal assemblage and contains the Carlin gold mine along its northern margin. The Richmond Mountain thrust cuts Ordovician to Devonian sedimentary rocks, which are intruded by an Early Cretaceous granite stock, a CretaceousTertiary(?) dike, by small Mesozoic(?) diorite dikes, and by Tertiary felsic dikes. The sedimentary rocks locally are converted to marble, dolomite and various calc-silicate mineral assemblages by contact metamorphism and metasomatism, particularly along steep-dipping northwestand northeast-striking faults, and along the Richmond Mountain thrust. Both contact metamorphic and metasomatic assemblages are similar to those noted at the Mike deposit 4 to $5 \mathrm{~km}$ to the southeast.

The Richmond Mountain thrust lies between the Ordovician Eureka Quartzite and underlying Ordovician Pogonip Group and truncates west-dipping beds of Eureka Quartzite, demonstrating younger over older geometry, in contrast to the older-over- younger structural juxtaposition shown $t \times$ the Roberts Mountains thrust. The age and rature of the displacement on the Richnond Mountain thrust are equivocal, but field relations suggest the zone was active as early as Late Paleozoic, and reactivation may have taken place in the late Mesozoic. Movement along the Richmond Mountain thrust has been suggested previously to be related to extensional detachment faulting and doming due to emplacement of intrusives in the late Eocene to early Oligocene. The southwestern parts of the Richmond Mountain thrust also strike parallel with the Crescent Valley Independence Lineament (CVIL). In areas southwest of Richmond Mountain and at Bob's Flat farther th the southwest, evidence for the nortlrasttrending (CVIL) consists of nortl?astelongated ridges of folded and lc sally intensely tectonized rock in the upper plate of the Roberts Mountain thrust. SFatial association of strands of the Richmond Mountain thrust and northeast-striking, high-angle faults suggests that the thrust was active during at least one phase of movement along the CVIL. 


\section{Introduction}

This paper describes the Richmond Mountain thrust (Evans, 1974a,b, 1980) and related structures within the Crescent Valley-Independence Lineament (Peters, 1998) in the Paleozoic miogeoclinal assemblage of the southern Lynn Window (fig. 1). The Lynn window is in the Carlin trend of northern Nevada, which is defined by an alignment of gold deposits along a northwest-trending, 50-km-long and 8-kmwide belt (Roberts, 1960, 1966; Madrid and Roberts, 1990; Teal and Jackson, 1997). Most gold deposits are associated with an Ordovician to Devonian miogeoclinal assemblage in tectonic windows through Ordovician to Devonian rocks of deep water origin in the upper-plate of the Roberts Mountains thrust (fig. 1). Geometric relations of the Richmond Mountain thrust to folds and faults in the Lynn window provide evidence for a complex geologic history of the window and lend understanding to the relations of gold deposits to structures in and near the window.

Field work was conducted in 1997 using $(1: 6,000) 1^{\prime \prime}=500^{\prime}$ topographic maps, provided by Newmont Exploration Ltd., which also provided geochemical analysis of rock samples (plate 1). Outcrop-style mapping was conducted in order to document structures and lithology related to the Richmond Mountain thrust. Previous structural studies by the author focused previously on areas in the southern part of the Carlin trend (Peters, 1997a) to the west and north of the Lynn window (Peters, 1997b), in the north-central part of the Carlin trend (Peters, 1997c), and along the zone of the Crescent Valley-Independence Lineament, which passes through the Richmond Mountain area (Peters, 1998) (fig. 1).

\section{General Geology}

Early and middle Paleozoic, deepwater sedimentary and igneous rocks were thrust eastward approximately 75 to $200 \mathrm{~km}$ during the Late Devonian to Early
Mississippian Antler orogeny (Roberts and others, 1958; Roberts, 1966). These rocks compose the Roberts Mountains allo-hthon, which lies upon coeval shallow-water rocks of the continental platform. These two packages of rocks, the upper and lowerplates, are separated by the Roberts Mountains thrust (Merriam and Anderson, 1942; Roberts and others, 1958). Emplacement of the allochthon produced a topographic high, which shed setiments that range in age from Mississipian to early Permian into a foreland basin. These rocks constitute the overlap assemblage of rocks, to the east and west in the late Paleozoic (Roberts, 1960; Madrid and others, 1992; Theodore and others, 1998). Mesozoic tectonism consisted mainly of compression that resulted in folding and thrusting (Saleeby and Busby-Spera, 1992, Cowan and Bruhn, 1992, and Miller and others, 1092).

Other reconstructions of the tectonic history of the region suggest that some geologic relations also may be due to: (1) local Early Triassic remobilization of the Roberts Mountains allochthon (Ketner and Alpha, 1992; Ketner and others, 1993); (2) significant tectonism in the region during the Late Jurassic Elko orogeny (Thorman and others, 1990); (3) the Cretaceous to Early Tertiary Sevier orogeny; and (4) large-scale extensional detachment faulting in the late Eocene to early Oligocene (Thorman and others, 1991a, b; Seedorff, 1991; W'allace, 1991), local Eocene volcanism (Herry and Boden, 1998) (fig. 1). Rocks of the Carlin Formation-Tertiary sedimentary rocks on fig. 1-fill most of the extended basins.

Many sedimentary rock-host?d gold deposits in north-central Nevada cl ister in mining districts that lie along northwesttrending belts (Roberts, 1960, 1966), or are associated with regional-scale lineaments (see Shawe, 1991). Belts and lineaments are compatible with genetic theories of the formation of sedimentary rock-hosted gold deposits, which call for deep-seated, overpressured fluids and associated conduits (Kuehn and Rose, 1995). 


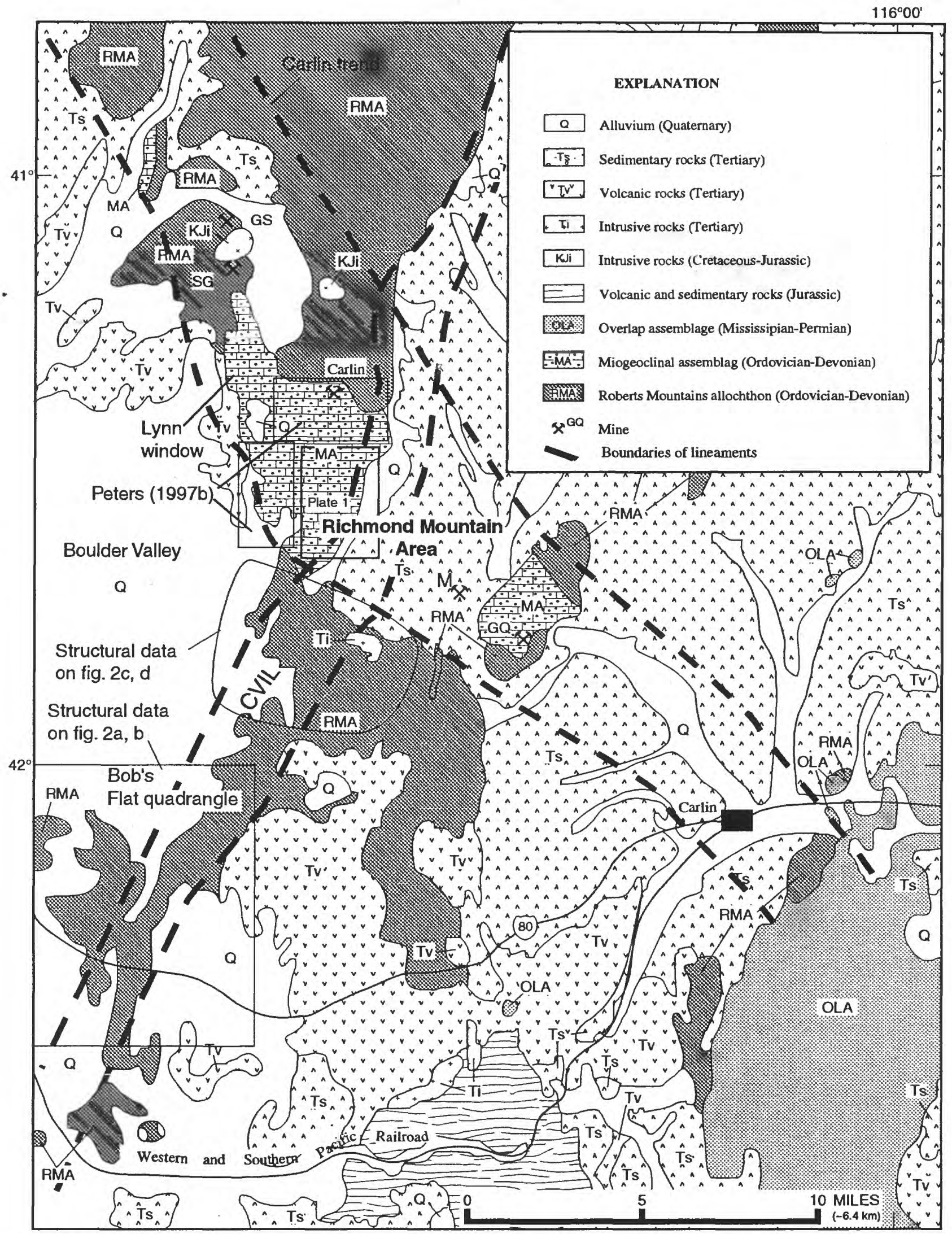

Figure 1. Generallzed geology of the Carlin trend (modified from Stewart and Carlson (1976). Rectangles show location of study areas in the northern Lynn-Carlin window described in this report: plate 1 = Richmond Mountain area. Also note Area of Bob's Flat quadrangle, south Fichmond area and location of areas studied in Peters (1997b). Most mines are located along a NW-trending zone associated with tectonic windows of lower-plate DevonianOrdovician miogeoclinal assemblage rocks (MA), which under lie the Devonian-Ordovician Roberts Mountains allochthon (RMA). The major upper-plate unit exposed in the Cárlin trend area in the AMA is Ordovician Vinini Formation. Mlssissippian-Permian overlap assemblage rocks (OLA) are present in the SE part of the map area. Major mines are noted as follows: $G Q=$ Gold Quarry, $S G=$ Genesis-Blue Star, $G S=$ (Goldstrike), $M=$ Mike deposit. 

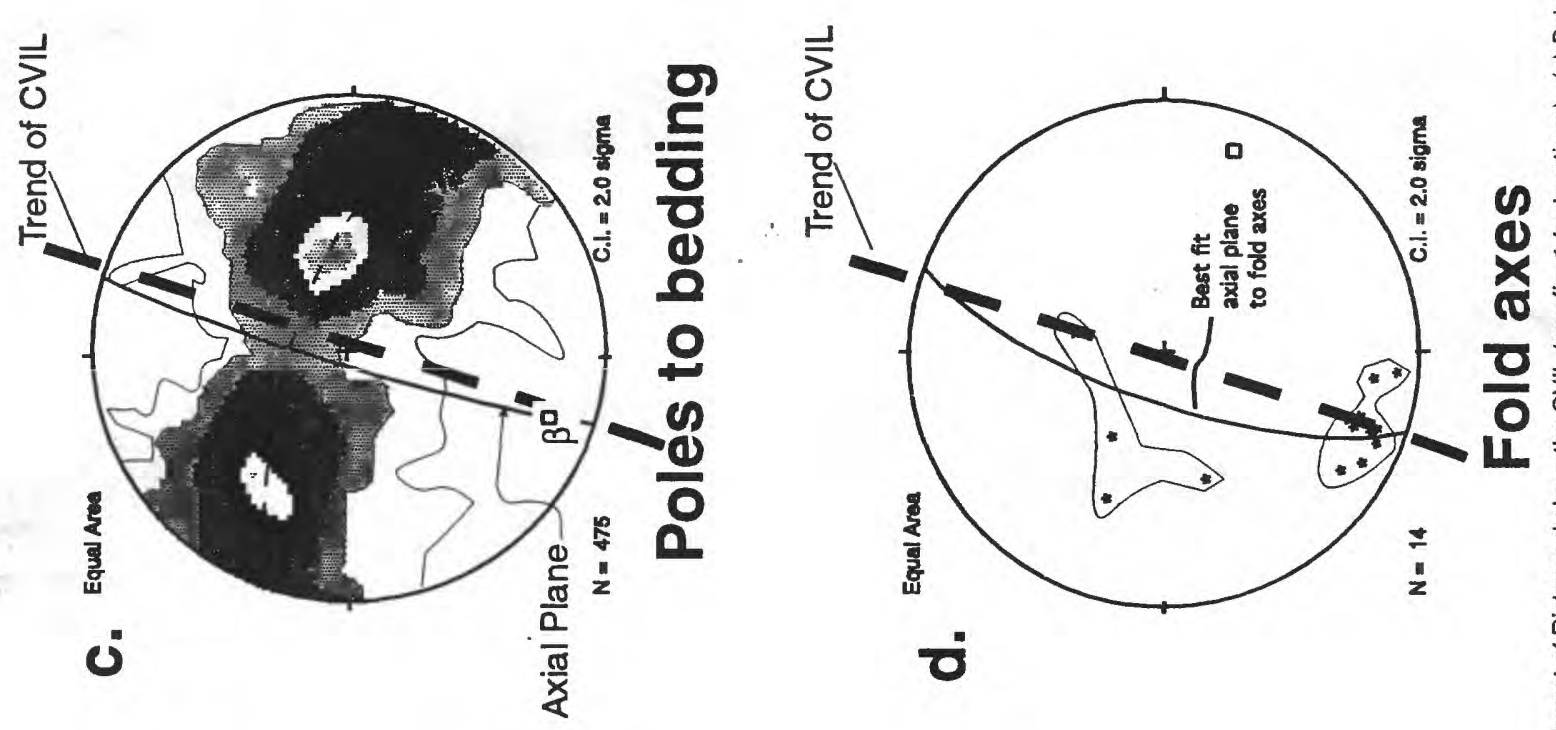

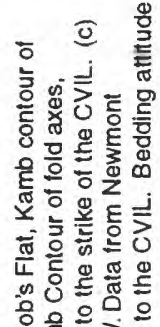

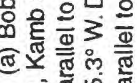

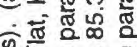

는

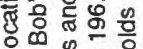

(1) 흐르응흐뭉

15.

일 \& ऐ응 중 螎 运要 응 동응 웅

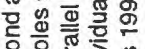

ह응

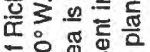
के

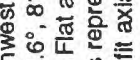
डैक्षे

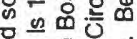
政

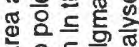
는등 흔 음 온 은 웅

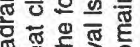

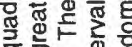
흐르응 때원
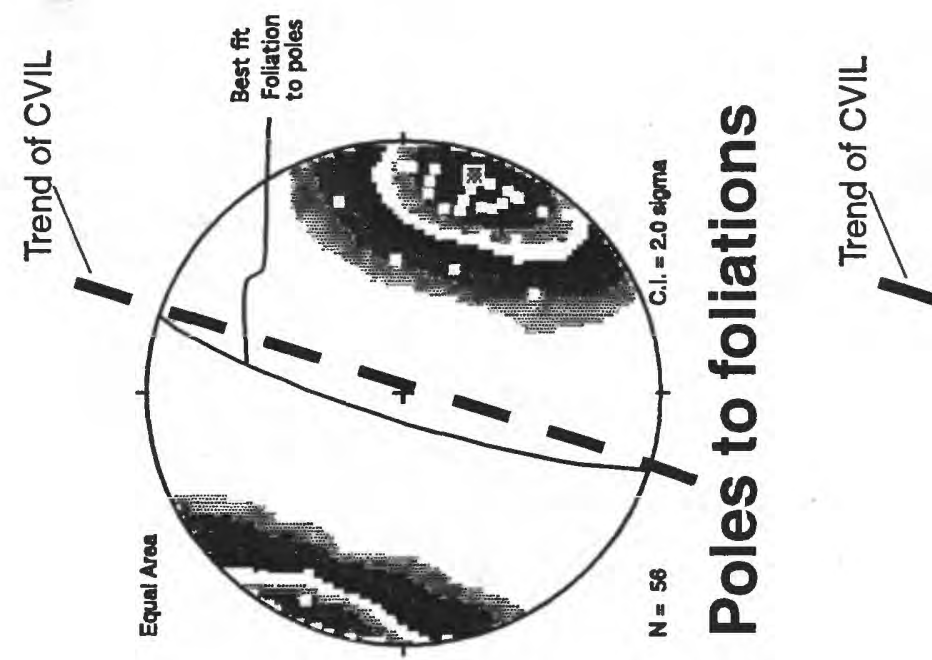
응 즈음

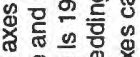

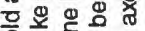
은 흔응응 뭉

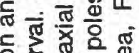
을 충 은든음응 뭉 흔을 항

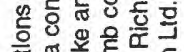

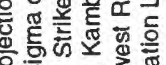

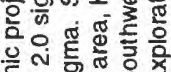
올 틍 혛

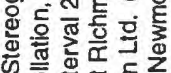


Lineaments have been postulated to be regional conduits for deep-sourced metalbearing fluids (Kerrich, 1986; Kerrich and others, 1994) and may have been active during hydrothermal events and therefore may have interacted with these fluids near or in the ore depositional environment (Phillips, 1986). Faults in the Richmond Mountain area may have served as conduits for hydrothermal fluids, as shown by alteration and anomalous metal values within them (pl. 1). These faults also may have been linked to deformation along the Carlin trend and the Crescent ValleyIndependence lineament (CVIL) in northcentral Nevada (Peters, 1998). The CVIL is defined by Late Paleozoic to Tertiary shearing, brecciation, mélange formation, folding, Mesozoic and Tertiary igneous intrusion, and hydrothermal activity along a $\mathrm{N} 20^{\circ} \mathrm{E}$ - to $\mathrm{N} 30^{\circ} \mathrm{E}-$ striking zone (fig. 1).

In areas southwest of Richmond Mountain and at Bob's Flat (fig. 1), evidence for the CVIL consists of northeast-trending ridges of folded and locally intensely tectonized basinal eugeoclinal rock of the upper-plate of the Roberts Mountains thrust (Peters, 1998). On average, tectonized fabric, foliation-defined by $\mathrm{mm}$-scale shear zone layering - and intense jointing strike $\mathrm{N} 10^{\circ} \mathrm{E}$ and dip steeply or are vertical (fig. 2). Between the Richmond Mountain area and Bob's Flat the upper-plate rocks have mesoscopic and megascopic fold axial planes and axes of conical folds that consistently trend northeast and southwest, parallel to the trend of the CVIL (figs. 1 and 3). The southwest part of the Richmond Mountain thrust (not shown on plate 1) also strikes parallel with the CVIL.

\section{Summary of Lynn window geology}

The largest window in the Roberts Mountains allochthon along the Carlin trend is the Lynn window (Evans 1974a, b, 1980); the Richmond Mountain area is at the approximate center of the window (fig. 1). The Richmond Mountain area contains the Richmond Mountain thrust that overrides
Ordovician to Devonian rocks, which are intruded by the Early Cretaceous Richmond granite stock, the Mesozoic and/or Tertiary? Richmond dike, and several small felsic Tertiary dikes. The sedimentary roc's and parts of the Richmond Mountain thrust locally are contact metamorphosed (pl. 1). Foliation and other deformation fabrics are not present in the intrusions or in contact metamorphosed sedimentary rocks, suggesting that they formed during periods of dilation rather than compression. Along the southeast facing range front, a nor'heasttrending zone of jasperoid, breccia, calcite veining, and decalcification crops out (pl. 1). Hydrothermal alteration along the range front and displacement along the Richmond Summit fault (Evans, 1980) indicate both hotspring or epithermal as well as tectonic activity in the Tertiary (pl. 1). Injection of the Richmond dike and Richmond stork also suggest that areas along the CVIL underwent dilation during the Late Mesozoic.

\section{Sedimentary rocks}

Miogeoclinal rocks exposed in the Richmond Mountain area consist of the 1,100ft-thick (335 m) Ordovician Pogonip Group composed of thick-bedded dolomite and thinbedded limestone. This unit has been interpreted by Evans (1980) to contain strata belonging to the Cambrian $\mathrm{H}=$ mburg Dolomite in its basal parts. These rorks are overlain by the 1610 -ft-thick $(499 \mathrm{~m})$ Ordovician Eureka Quartzite, which is a thick- to thin-bedded quartzite and sandy dolomite. These rocks are overlain by the Ordovician and Silurian Hanson Creek Formation, an approximately 1,000-ft-thick (305 m), black to dark gray, fine-grained, thick-bedded to massive dolomite with bioclastic debris and chert.

In the northern and southwestern parts of the Lynn window (fig. 1; see also, Peters, 1997b), the Hanson Creek Formation is overlain by approximately $1,500 \mathrm{ft}(457 \mathrm{~m})$ of Silurian and Devonian Roberts Mordntains Formation. A Devonian unnamed limestone of Evans (1980), referred to locally is the Popovich limestone, overlies Foberts 
Mountains Formation. The Devonian unnamed limestone may be equivalent to the Devonian limestone ( $\mathrm{Dl}$ on plate 1 ) designated by Evans on the southwest part of the Richmond Mountain area that consists of a gray, finegrained, thin- to thick-bedded limestone, locally altered to white marble. The exposures of these units is poor in the south part of the window and their primary sedimentary outcrop textures are altered due to contact metamorphism (see also, fig. 7, p. 24 of Evans, 1980).

Rocks assigned to the Ordovician Pogonip Group lie in and surround sec. 36, T. 35 N. R. 50 E. (pl. 1). The central and eastern parts consist of gray dolomite with common white, 1- to 3-cm-wide dolomite and marble layers. Locally, as much as 100-m-thick layers consist of white, massive marble. These rocks were originally assigned by Evans $(1974 a, b)$ to the Pogonip Group, but parts, particularly the white marble, were reassigned by Evans (1980) to rocks of the Cambrian Hamburg Dolomite on the basis of stratigraphic relations and lithology, and also coincide with areas of contact metamorphism noted on plate 1 and by Evans $(1974 a, b)$. The central dolomitic rocks are overlain by gray, poorly exposed limestone (Ls, plate 1), much of which is obscured by talus from overlying Eureka Quartzite. Dolomite of the Pogonip Group also is present to the north in parts of secs. 25 and 26, T. $35 \mathrm{~N}$. R. 50 E., but shows less intensely develop contact metamorphic fabrics (pl. 1).

The Eureka Quartzite lies above the rocks of the Pogonip Group and Paleozoic limestone (Ls). This contact locally thins the quartzite sequence and is, in most cases, the inferred trace of the Richmond Mountain thrust of Evans (1974a, b, 1980). The quartzite section in the upper-plate may be thickened by high-angle faulting in the W $1 / 2$ secs. 26 and 35, T. 35 N. R. 50E. Faultbound blocks of Eureka Quartzite are present in the SE1/4 sec. 35, T. 35 N. R. 50 E. along the range front in NW1/4 sec. 2, T. 34 N. R. 50 E., and in E1/2 sec. 3, T. 34N. R. 50E. Quartzite in SE1/4 sec. 3, T. 34 N., R. 50 E., however, has no clear relation to quartzite in the upper plate of the Richmond Mountain thrust. Other quartzite blocks along the range front, north of SE1/4 sec 3 T. 34 N., R. 50 E. may be down-dropped blocks of upper-plate of the Richmond Mountain thrust and may imply Early Tertiary extension in the Rirhmond Summit fault zone along the CVIL. A thinned 100- to 200-m-thick slice of Eureka Q xartzite is present south of the Richmond stock (pl. 1).

Black to dark gray, thick-bedded and massive fine-grained dolomite, assigned to the Ordovician and Silurian Hanson Creek Formation, lies depositionally upon the Eureka Quartzite (Evans, 1974a,b, 1987). The distribution and designation of units on plate 1 in the south part of sec. 35 T. 35 N. R. 50 E., and the north part of sec. 3, T. 34 N. R. 50 E., differ slightly from those designated by Evans (1980).

\section{Igneous Rocks}

The Early Cretaceous Ri-hmond granite stock (K-Ar age of $106 \pm 5.0 \mathrm{Ma}$, Evans, 1980), Cretaceous-Tertiary? Ri-hmond dike, and Mesozoic(?) diorite dikes intrude sedimentary rock units in the Lynn window and coincide with areas of mild to intense contact metamorphism and metasonatism. Tertiary dikes composed of quartz-poor and quartz-feldspar-biotite latite dikes are present generally outside areas of contact metamorphism or are located along faults, which truncate areas of contact metamorphic rocks (pl. 1).

The Richmond composite stock is a coarse-grained biotite-oligoclase potassiumfeldspar quartz monzonite to granite with phenocrysts of quartz and $\mathrm{K}$-feldspar (perthite). It is surrounded on the north and west by Eureka Quartzite. The bedding attitudes in the quartzite indicate that the stock was intruded into the central parts of a northwest-trending fold (pl. 1).

The Richmond dike is composed of two rock types. The northeastern $300 \mathrm{~m}$ of the dike forms a forked tip near the range front (pl. 1), and consists of hypabyssal, porphyritic, vertically jointed rhyolite with quartz, sanidine, biotite, and muscovite phenocrysts, and has textures and miroralogy 
similar to Tertiary age dikes along the Carlin trend (M. W. Russell, oral comm., 1999). The rest of the dike is hypabyssal quartz monzonite, as noted by Evans (1980), and consists of propyllitized dacite with biotite, hornblende, plagioclase with minor quartz, and $\mathrm{K}$-feldspar. The hypabyssal texture and mineralogy in both parts of the dike are similar to Tertiary igneous rocks along the Carlin trend, but the spatial association with the Richmond granite stock and the contact metamorphic rocks suggest that an Early Cretaceous age also is possible. Geochemically the dike has many similarities to the Richmond granite stock (Evans, 1980).

A small swarm of black, dense, hard diorite dikes (di) is present in contact metamorphosed Pogonip Group rocks in the center of sec. 36, T. 35 E. R. 50 E.; the dikes are tentatively assigned to the Mesozoic (pl. 1) on the basis of their association with the contact metamorphism, their non-hypabyssal texture, and their similarities to lamprophyric dikes reported in the Mike deposit by Teal and Branham (1997).

Poorly exposed dikes of probable Tertiary age strike east-west as $0.5-$ to $2-\mathrm{m}$ thick, isolated, outcrops and scree occurrences. They are composed of tan, altered, quartz feldspar-biotite porphyry (Tgd, pl. 1, sec. 26, T. 35 E., R. 50 E.). Thin, quartz poor, creamcolored, feldspar-porphyry latite dikes crop out as east-northeast-striking dikes along faults in the southeast part of plate 1 . These quartz-poor dikes have petrologic similarities to Miocene rhyolitic volcanic rocks on the west side of Boulder Valley (fig. 1) (Ludington, oral commun., 1996).

An apophyse of granite extends southwest from the Richmond stock and parallels faults along the Crescent Valley Independence lineament (Peters, 1998). The types of intrusive rocks and associated contact metamorphism and metasomatism in the Richmond Mountain area are similar to Late Mesozoic intrusive rocks and rock alteration at the Mike deposit (Teal and Branham, 1977).

\section{Contact metamorphism and metasomatism}

Calc-silicate rocks, skarn, and marble are common but localized rock types in the Richmond Mountain area (pl. 1). Calcsilicate zones, composed of actinolite and tremolite and disseminated pyroxene and garnet, in the lower parts of the Fogonip Group in sec. 36, T. 35 E. R. 50 E. commonly are mixed with broad zones of marble and recrystallized dolomite ( $p l .1$ ). In the calcareous and dolomitic rocks, sedimentary bedding and layering is destroyed in areas of coarse-grained skarn that contains garnet, pyroxene, hornblende, talc, serpentine, tremolite, scapolite, magnetite, sulfide minerals, and other minerals (see Evans, 1980). Small areas of skarn are present inside the broader zones of calc-silicate ro-k and also are present along northwest- and northeast-striking faults and fissures. Skarn minerals replace dolomitic layers in the upper parts of the Eureka Quartzite forming layered brown-, green- and tan-colored rocks adjacent to faults and fissures.

Because much of the intense contact metamorphism and metasomatism is localized along faults and fissures, rather than along bedding units, it is likely that these structures served as pathwavs for metasomatic fluids. This is particularly true along northwest-striking faults-such as the South Richmond fault-and along nor'heaststriking faults and fissures, such as that filled by the Richmond dike (pl. 1). The propensity for contact metamorphi- and metasomatic assemblages to be localized along faults and fissures is similar to the presence of these assemblages in elongated zones at the Mike deposit to the southeast (Teal and Branham, 1997).

\section{Structure}

The main low-angle structure in the center of the Lynn window is the Richmond Mountain thrust (pl. 1). Other low'-angle faults, mapped by Evans (1980) in the area are southwest of the Richmond granite stock. The main northwest-striking high-angle 
faults are the South (Evans, 1980) and North Richmond fault zones (pl. 1). Other structures in the Richmond Mountain area are highand low-angle fault zones, many of which are roughly parallel to axial planes of folds. In some cases, faults may have been reactivated.

The Richmond Mountain thrust lies between the Eureka Quartzite and Pogonip Group and truncates Devonian rocks in the southwest part of plate 1 (see Evans, 1980). The surface of the thrust is usually obscured by scree (Qc, pl. 1) from the overlying outcrops of Eureka Quartzite and therefore precise location of the trace of the Richmond Mountain thrust on is open to some question. Evidence for the Richmond Mountain thrust cited by Evans (1980) is truncation of the northwest-striking, high-angle South Richmond fault and local truncation of bedding in the lower-plate rocks of the Roberts Mountains allochthon (pl. 1, see also Evans, 1980). The geometry of the thrust appears to be near-horizontal through much of the Lynn window, but southwest extensions shown by Evans (1980) indicate steep westdipping to near-vertical.

The South Richmond fault, which is offset by the Richmond Mountain thrust, offsets east-northeast-striking Tertiary(?) latite dikes, suggesting that some movement along the Richmond Mountain thrust is younger than these dikes (pl. 1). Additional sites of evidence for the Richmond Mountain thrust along the base of the Eureka Quartzite are: (1) a $>700-\mathrm{m}$-long zone of calc-silicate rock, breccia and gossan in SW1/4 sec. 35, T. 35 N. R. 50 E., (2) a 150-m-thick brecciated base and thinning of the Eureka Quartzite in the northwest Richmond Mountain area (center sec. 26, T. 34 E. R. 50 E.), and (3) jasperoid at the Eureka Quartzite-Pogonip Group contact (W1/2 sec. 25, T. 35E. R. 50E.). The Richmond Mountain thrust is truncated by the northwest-striking North Richmond fault zone $(W 1 / 2 \sec 25$, T. 35 E., R. 50 E.); however the extension of the thrust on the east side of the to the east may be covered by scree along the range front.

The Richmond Mountain thrust has cross-cutting relations with a number of sedimentary units and faults that indicate its complex structural history in the Lynn window. Several interpretations of ages of movement, associated igneous activity, contact metamorphism and metasomatism, and stratigraphic juxtaposition are possible. Because the thrust closely follows and is the contact between the Pogonip Group and Eureka Quartzite, movement may be less than 100 to $500 \mathrm{~m}$, although truncation of Devonian rocks under the thrust mapped by Evans (1980) may imply a greater offset. Contact metamorphism and metasomatism along the South Richmond fault zone and along parts of the Richmond Mountain thrust can be inferred to be Early Cretaceous on the basis of the age of the Richmond granite stock and on late Mesozoic ages reported for similar rocks in the Mike Deposit (Teal and Branham, 1997). This is compatible with the interpretation of the ages of movement of the Good Hope fault in the Mike Deposit-a probable extension of the South Richmond fault zone-also discussed by Teal and Branham (1997). Stratigraphic and geometric relations near the Richmond Mountain thrust and the South Richmond fault are complex; rock units and fault geometries differ slightly between plate 1, Evans (1974a, b), and Evans (1980), but indicate that pre- or syn-Early Cretaceous ages for movement(s) along the Richmond Mountain thrust are likely.

The strike of the Richmond Mountain thrust changes on the southwest edge of plate 1 and the fault continues to the so'uthwest with a more vertical dip (Evans, 19?9). If this southwest-striking part of the fault had a strike-slip component, this is permissive with parts of the thrust having a northeastsouthwest transport direction. Southweststriking thrust faulting also has been inferred by Evans (1974a, b, 1980) along the thinned beds of Eureka Quartzite south of the Richmond granite. Solely on the basis of strike and position within the CVIL corridor, the southwest-striking thrusts may be related to the same tectonism that is associated with the movement along the CVIL. Because these thrusts lie in and are locally parallel to the CVIL, movement along them may be related to tectonic activity, which created northeastsouthwest-striking faults, folds, and linear 
fabrics along the CVIL. By inference, the southwest-striking strand of the Richmond Mountain thrust, and therefore also the more shallow-dipping parts of the thrust, is most likely related to movement along the CVIL. These geometries are suggest that horizontal movement along the Richmond Mountain thrust is compatible with northeast strikeslip movement along the CVIL.

High-angle, northeast-striking faults cut outcrops of Eureka Quartzite in the NW1/4 sec. 35, T. 35 E. R. 50 E. and are marked by zones of calc-silicate rock at the margins or centers of these fault zones. These faults are parallel to the Richmond dike, which also is contained in a broad zone of calc-silicate rock and skarn, suggesting that this northeast-oriented rock mass was dilated in a northwest direction during the metasomatic event (pl. 1). More east-striking faults are present in the south part of sec. 25, T. 35 N. R. 50 E., and are either filled with latite dikes or also are marked by zones of calc-silicate rock. These more east-striking faults contain Tertiary(?) quartz-poor latite dikes and acted as normal faults, which have down-dropped two blocks of Hanson Creek Formation and Eureka Quartzite at least 500 $m$ into the center parts of the Lynn window (SE1/4 sec. 35, T. 35 N. R. 50 E., and NW1/4 sec. 2, T. 34 N. R. 50 E.).

The northwest-striking South Richmond fault zone (pl. 1) is part of an even wider 800-m-wide zone of faulting and folding that contains the Richmond granite stock, its encompassing northwest-plunging fold, and zones of structurally controlled contact metamorphism and metasomatism. Other northwest-trending folds also are present to the west (pl. 1). The South Richmond fault zone is clearly truncated on the northwest by the Richmond Mountain thrust. The South Richmond fault zone is part of a broader tectonized zone that projects southeasterly into the valley under rocks of the Carlin Formation (not shown on pl. 1) The South Richmond fault is roughly parallel to and along strike of the Good Hope fault, a northeast-dipping reverse fault that hosts the Mike deposit and parts of the Gold Quarry deposit (see Teal and Branham, 1997). A reverse sense of movement also is inferred on the South Richmond fault with the east side down.

The northwest-striking North Richmond fault zone (pl. 1) is marked by a 200 - to 300-m-wide zone of bre-ciated quartzite that also contains local areas of jasperoid as matrix fill in the breccia. This fault may extend at least $3 \mathrm{~km}$ to the northwest-on the basis of topographic lineaments, mapped faults and stratigraphic offsets documented by Evans (1974a)-and is roughly parallel to the northwest-striking Post, Gen and Leeville faults associated with gold deposits (Fig. 3; see also Teal and Jackson, 1997) along the northern part of the Carlin trend. Outcrops along the south part of the fault contain layered, rather than brecciated, jasperoid where the eastern trace of the Richmond Mountain thrust would be projected (center of sec. 25, T. 35 N. R. 50 E.; sample 1729, pl. 1). These layered jasperoids could represent parts of the Richmond Mountain thrust that were incorporated in the North Richmond fault zone, or may represent foci of movement--similar to zones of silicified fault gouge-in the North Richmond fault zone. The southeast end of the North Richmond fault zone on plate 1 is covered by colluvium, but probably extends to the range front on the basis of geomorphologic expression (pl. 1).

Folding in the Richmond Mountain area includes part of a broad asymmetric, shallow, northwest-plunging Lynn anticline (Evans, 1980) as indicated by the outline of the Eureka Quartzite outcrops around the bowl-shaped topography of the Richmond Mountain area (pl. 1). Folds in the rocks of the Pogonip Group and Hamburg Dolomite(?) are more northerly and horizontally plunging and are represented by a 1-km-wide arch. A 200- to 300-m-wide northwest-plungir gold is present in the Eureka Quartzite southeast of the South Richmond fault and contains the Richmond granite stock in its core (pl. 1). Orientations of these mega- and macroscopic folds in the Lynn window contrast with the strong and uniform northeast-trending mesoscopic fold axes and axial planes in upper-plate rocks to the southwest along the CVIL (fig. 2). This suggests that either lower-plate rocks were deformed seperately 
from the upper-plate rocks, and (or) that they have been refolded locally in the vicinity of the Carlin trend (see Peters, 1996).

\section{Mineralization and Geochemistry}

Three main styles of $\mathrm{h}$ mineralized rocks are present in the Richmond Mountain area: (1) early skarn- and contact metamorphic-related zones, (2) jasperoid and breccia zones along faults, and (3) relatively young zones of decalcification and jasperoid breccia along the range front (pl. 1). These three types of mineralized rocks locally may overprint one another. Geochemical analysis of altered rock samples from these different styles, taken in the Richmond Mountain area, are contained in table 1.

Areas of skarn and contact metamorphic rocks are present in low hills on the east side of plate 1 , occupied by Pogonip Group (Hamburg Dolomite?) rocks, and aIso along faults in the western upper hills in the Eureka Quartzite and Hanson Creek Formation. Gossan is common in Iocal intensely metasomatised areas and has similar characteristics-such as abundant, massive hematite and limonite and "earthy" gossan-to the supergene iron zones described by Teal and Branham (1997) in the Mike deposit. Gold contents are associated with high copper concentrations in the Pogonip Group rocks (samples 1747 to 1752, table 1) and have associated elevated contents of silver, mercury, antimony and zinc. Massive magnetite is common in many skarn zones. Northwest-striking faults and parts of the Richmond Mountain thrust zone contain most iron-rich areas (pl. 1).

The North Richmond fault zone (pl. 1) contains rocks with anomalous concentrations of antimony, arsenic, and mercury associated with jasperoid matrix and seams in the breccia (table 1). These are common pathfinder elements of gold deposits along the Carlin trend and therefore suggests that silicification along the fault was accompanied by fluids that carried metals characteristic of the main Carlin-type deposits to the northwest along the Carlin trend. Jasperoid along the range front contains elevated concentrations of mercury (table 1, pl. 1).

\section{Discussion and Conclusicns}

Although IocaI expressions of the Richmond Mountain thrust are present along the contact between the Pogonip Gro'sp and the Eureka Quartzite-such as brec-iation, silicification and iron-rich metasomatized zones-lack of apparent major offset retween the Eureka Quartzite and the overlying Hanson Creek Formation suggests that movement along the fault could be less than $500 \mathrm{~m}$. However, because the southweststrike of the more steeply-dipping southwest strands of the thrust paralleI structure: in the CVIL, movement along parts or all of the Richmond Mountain thrust may have been related to movement associated with strands of the CVIL and therefore could be greater than $500 \mathrm{~m}$ (fig. 3).

On a mining district scale, orientation and geometric relations among faul's and associated tectonic fabrics in and near the Lynn window help constrain the timing of events within it. For instance, most fold axes in upper-plate Paleozoic-age rocks in the Carlin trend area plunge at low angles to the northeast and southwest (Evans and Theodore, 1978; Peters, 1996), and roughly paralleI the CVIL; however, fold axes near and in the window plunge at shallow angles to the north and northwest (Evans and Theodore, 1978; Madrid, 1987; Madrid and Bagby, 1986; Peters, 1996, 1997a).

The northeast-trending fold axes, fold axial planes, foliation and jointing along the CVIL resulted from multiple deformations that took place betwe on the Late Permian and Late Jurassic, during the HumboIdt, Sonoma and (or) Elko orogenies (Peters, 1997d, 1998). Folding and transposition of bedding and shearing in the tectonized zones along the CVIL impl:' local north-south shortening (see Theodore and others, 1998). One or more movements of the Richmond Mountain thrust during this 
Table I (ieochemical Analysis of selected rock samples from the Richmond Mountain area

\begin{tabular}{|c|c|c|c|c|c|c|c|c|c|c|c|c|}
\hline SAMPLE & NORTII & EAST & FIELD DESCRIPTION & Au oz/t & $\begin{array}{r}\text { A g } \\
\text { pem }\end{array}$ & $\begin{array}{c}\text { As } \\
\text { ppm }\end{array}$ & $\begin{array}{c}\mathrm{Cu} \\
\operatorname{epm}\end{array}$ & $\begin{array}{c}\text { Fe } \\
\text { Ppm }\end{array}$ & $\begin{array}{c}\mathbf{H g}_{\mathbf{g}} \\
\operatorname{pgm}\end{array}$ & $\begin{array}{c}\mathbf{P b} \\
\mathbf{p p m}\end{array}$ & $\begin{array}{c}\text { Sb } \\
\text { ppm }\end{array}$ & $\begin{array}{c}\mathrm{Zn} \\
\mathrm{PPm}\end{array}$ \\
\hline 1703 & 4525375 & 557013 & quartzite $w / 0.5 \mathrm{~cm} q t z$ veinlets, orange & $<0.005$ & $<0.2$ & 6 & 5 & 0.30 & 10 & $<1$ & 2.4 & 13 \\
\hline 1704 & 4525475 & 557380 & quartzite, pitted with vugs lined $w /$ lm & $<0.005$ & 0.8 & 50 & 6 & 0.60 & 210 & 83 & 40 & 75 \\
\hline 1705 & 4525140 & 55775 & feldspar qtz porph. dike, It yellow & $<0.005$ & $<0.2$ & 50 & 7 & 0.40 & 500 & 6 & 9.2 & 30 \\
\hline 1706 & 4525040 & 55785 & pitted quartzite $w / 0.5 \mathrm{~cm}$ void, orange & $<0.005$ & $<0.2$ & 12 & 51 & 0.30 & 130 & 5 & 6.6 & 16 \\
\hline 1707 & 4525055 & 558163 & pyritic black chert nodule, laminar banding & $<0.005$ & $<0.2$ & 6 & 11 & 0.95 & $<10$ & 3 & 0.4 & 17 \\
\hline 1708 & 4525035 & 558350 & porphyroblastic calc-silicate, gray $0.5 \mathrm{~cm}$ pyx & $<0.005$ & $<0.2$ & 8 & 8 & 0.40 & 10 & 2 & 1.2 & 10 \\
\hline 1709 & 4525060 & 558510 & quartzite breccias red $\mathrm{cm}$-scale jasperoid seams & $<0.005$ & $<0.2$ & 14 & 9 & 0.40 & 110 & 2 & 12.0 & 12 \\
\hline 1710 & 4525015 & 558585 & jasperoidal dolomite, pitted, boxworks, red & $<0.005$ & $<0.2$ & 500 & 14 & 2.15 & 13700 & $<1$ & 610 & 370 \\
\hline 1711 & & & Hanson Creek fm, breccia with red rind & $<0.005$ & $<0.2$ & 28 & 9 & 0.25 & 440 & 8 & 24 & 14 \\
\hline 1712 & 4525925 & 558043 & quartzite breccia, jasperoid matrix and seams & $<0.005$ & $<0.2$ & 1 & 13 & 0.60 & 30 & 3 & 3.6 & 8 \\
\hline 1713 & 4525955 & 558080 & quartzite breccia, white and red jasp. matrix & $<0.005$ & $<0.2$ & 1 & 6 & 0.45 & 50 & 10 & 2.4 & 12 \\
\hline 1714 & 4525860 & 558130 & quartzite breccia, red jasp. matrix & $<0.005$ & $<0.2$ & 2 & 7 & 0.40 & 40 & $<1$ & 2.2 & 6 \\
\hline 1715 & 4525720 & 558130 & quartzite breccia, red jasp. matrix & $<0.005$ & $<0.2$ & 34 & 11 & 0.50 & 110 & 5 & 68 & 22 \\
\hline 1716 & 4525750 & 558040 & quartzite breccia, veinlets and matrix of red jasp. & $<0.005$ & $<0.2$ & 6 & 8 & 0.30 & 20 & $<1$ & 18.0 & 8 \\
\hline 1717 & 4525770 & 558030 & quartzite with brwn stain and jasp. veinlets & 0.006 & $<0.2$ & 296 & 16 & 1.20 & 160 & 37 & 580 & 88 \\
\hline 1718 & 4525685 & 557975 & massive quarzite w/ seamlets of red jasp. & $<0.005$ & $<0.2$ & 12 & 23 & 0.95 & 30 & 12 & 35 & 16 \\
\hline 1719 & 4525600 & 558015 & banded quartzite, black calc-silicate rock, Im & $<0.005$ & $<0.2$ & 12 & 7 & 0.55 & 140 & 5 & 15.0 & 27 \\
\hline 1720 & 4525735 & 558154 & red jasperoidal quarzite breccia with seamlets & $<0.005$ & $<0.2$ & 4 & 22 & 0.95 & 50 & 2 & 5.2 & 12 \\
\hline 1721 & 4525850 & 558240 & quarzite breccia, red jasp. matrix & $<0.005$ & $<0.2$ & 8 & 18 & 0.75 & 20 & 2 & 3.2 & 10 \\
\hline 1722 & 4525825 & 558300 & red jasperoid, leached, carbonate vugs & 0.0013 & $<0.2$ & 910 & 19 & 2.45 & 830 & 27 & 230 & 360 \\
\hline 1723 & 4525790 & 558250 & quarzite breccia, red jasp. matrix, beavy brx. & 0.0012 & 1.4 & 70 & 11 & 0.75 & 670 & 75 & 15.5 & 52 \\
\hline 1725 & 4525715 & 558315 & quartzite breccia, white jasp. matrix, flat clasts & $<0.005$ & $<0.2$ & 6 & 5 & 0.35 & 30 & 3 & 2.4 & 9 \\
\hline 1726 & 4525630 & 558295 & quartzite breccia, red jasp. matrix & $<0.005$ & $<0.2$ & 24 & 19 & 0.70 & 90 & 16 & 8.8 & 22 \\
\hline 1727 & 4525040 & 558375 & quartzite breccia, red jasp matrix & $<0.005$ & $<0.2$ & 38 & 16 & 1.40 & 110 & 3 & 30 & 220 \\
\hline 1728 & 4525070 & 558255 & quartzite breccia, white jasp. matrix, Im & $<0.005$ & $<0.2$ & 6 & 9 & 1.45 & 20 & 5 & 1.4 & 20 \\
\hline 1729 & 4525015 & 558450 & quartzite breccia, red jasp. matrix & 0.0034 & $<0.2$ & 90 & 21 & 0.60 & 210 & 8 & 18.5 & 130 \\
\hline 1730 & 4525250 & 557655 & Im vein in Fe-stained dolomite & $<0.005$ & $<0.2$ & 390 & 16 & 5.30 & 2730 & 4 & 32 & 28 \\
\hline 1731 & 4525250 & 557655 & altered dolomite and qtz feld. porph., orange & $<0.005$ & $<0.2$ & 176 & 9 & 1.20 & 830 & 9 & 11.5 & 25 \\
\hline 1732 & 4524375 & 558600 & dolomite breccia, jasperoidal, boxworks & $<0.005$ & $<0.2$ & 148 & 8 & 0.60 & 40 & 6 & 46 & 62 \\
\hline 1733 & 4524375 & 558635 & dolomite breccia w/ red jasp matrix, boxworts & $<0.005$ & $<0.2$ & 48 & 12 & 0.40 & 120 & 58 & 26 & 52 \\
\hline 1734 & 4524380 & 558565 & dolomite breccia w/ jasp matrix, red-orange & $<0.005$ & $<0.2$ & 14 & 5 & 0.20 & 10 & 14 & 8.8 & 32 \\
\hline 1735 & 454475 & 558425 & dolomite breccia in red jasp. matrix, calcite vns. & $<0.005$ & $<0.2$ & 130 & 11 & 0.45 & 380 & 6 & 37 & 67 \\
\hline 1736 & 452485 & 558500 & red and orange jasperoid, pitted, leached & $<0.005$ & $<0.2$ & 92 & 15 & 1.30 & 30 & 28 & 75 & 92 \\
\hline 1737 & 4524500 & 558575 & $\begin{array}{l}\text { dolomite breccia w/ white jasp. matrix, } \\
\text { boxworks }\end{array}$ & $<0.005$ & $<0.2$ & 32 & 7 & 0.20 & 40 & 7 & 14.0 & 30 \\
\hline 1738 & 4524545 & 558580 & jasperoid, yellow, orange, pitted, calcite vns. & $<0.005$ & $<0.2$ & 132 & 89 & 1.20 & 170 & 10 & 18.0 & 36 \\
\hline 1739 & 4525520 & 558625 & dolomite breccia in calcite matrix & $<0.005$ & $<0.2$ & 42 & 17 & 0.35 & 60 & 10 & 16.0 & 55 \\
\hline 1740 & 4524425 & 558750 & red jasperoid veinlet in dolomite, veining & $<0.005$ & $<0.2$ & 168 & 18 & 0.65 & 30 & $<1$ & 170 & 78 \\
\hline 1741 & 452440 & 558800 & stockwork calcite veining in dolomite, red & $<0.005$ & $<0.2$ & 46 & 7 & 0.40 & 10 & 3 & 96 & 60 \\
\hline 1742 & 4524330 & 559110 & red-brown quartzite breccia & $<0.005$ & $<0.2$ & 144 & 13 & 0.70 & 920 & 8 & 165 & 73 \\
\hline 1743 & 4524290 & 559095 & quartzite breccia, red-yellow-brown jasp matrix & $<0.005$ & $<0.2$ & 142 & 9 & 0.90 & 580 & 9 & 170 & 136 \\
\hline 1744 & 4524305 & 559125 & red jasperoid w/ calcite vein, boxworks, voids & $<0.005$ & $<0.2$ & 56 & 9 & 0.40 & 140 & 3 & 29 & 42 \\
\hline 1745 & 4524120 & 558865 & marble skarn $w /$ pyrite and calc-silicate & 0.0015 & 1.0 & 462 & 17 & 14.00 & 310 & 54 & 29 & 200 \\
\hline 1746 & 4524295 & 558900 & dolomite w/ stockwork, red jasp. veining & $<0.005$ & $<0.2$ & 246 & 9 & 0.70 & 30 & 6 & 270 & 88 \\
\hline 1747 & 4524275 & 558825 & dolomite/calc-silicate, red jasp. qtz vein, breccia & 0.0010 & 2.6 & 28 & 59 & 0.40 & 16400 & 50 & 24 & 7,000 \\
\hline 1748 & 4524080 & 558865 & dk. brown, porphyroblastic, pyrite and qtz. & 0.0047 & $<0.2$ & 1590 & 14 & $>20.00$ & 750 & 255 & 175 & 1,500 \\
\hline 1749 & 4524185 & 558615 & pitted pyrite-qtz rock & 0.0069 & 2.5 & 600 & 148 & $>20.00$ & 90 & 20 & 52 & 216 \\
\hline 1750 & 4524145 & 558015 & pyrite-silica rock, Im & 0.0064 & 0.5 & 308 & 92 & 17.0 & 150 & 15 & 52 & 305 \\
\hline 1751 & 4524180 & 558570 & pyrite-silica rock w/ qtz. veinlet & 0.0035 & 18.6 & 1450 & 203 & $>20.00$ & 6860 & 6800 & 220 & 950 \\
\hline 1752 & 4523940 & 55853 & chalcopyrite and malachite, gamet skarn & 0.0018 & 73.0 & 54 & $>10,000$ & 8.40 & 210 & 700 & 13.0 & 365 \\
\hline 1753 & 4523975 & 558665 & $q t 2$ vein, travertine, 1 inch thick & $<0.0005$ & 0.6 & 52 & 63 & 1.60 & 200 & 21 & 7.0 & 130 \\
\hline 1754 & 4522780 & 558445 & red and lyellow boxworks, pitted, jasperoidal & $<0.0005$ & $<0.2$ & 86 & 35 & 1.40 & 220 & 43 & 62 & 155 \\
\hline 1755 & 4522800 & 558445 & pitted jasp, calcite veints, red, brown, yellow & $<0.0005$ & 0.7 & 134 & 172 & 6.10 & 350 & 10 & 40 & 660 \\
\hline 1756 & 4523610 & 556015 & gossan, frothery, layered, calc-silicate and jasp. & $<0.0005$ & $<0.2$ & 152 & 40 & $>20.0$ & 350 & $<1$ & 8.8 & 72 \\
\hline 1757 & 452315 & 557265 & skarn veins (qtz), calc-silicate and limonite & 0.0026 & 94.0. & 264 & 340 & 0.65 & 2850 & $>10,000$ & $>1,000$ & $>10,000$ \\
\hline 1758 & 4522965 & 557750 & jasperoidal gossan, brown, frothy, boxworks & $<0.0005$ & 0.47 & 488 & 1320 & 5.60 & 270 & 800 & 220 & 560 \\
\hline
\end{tabular}




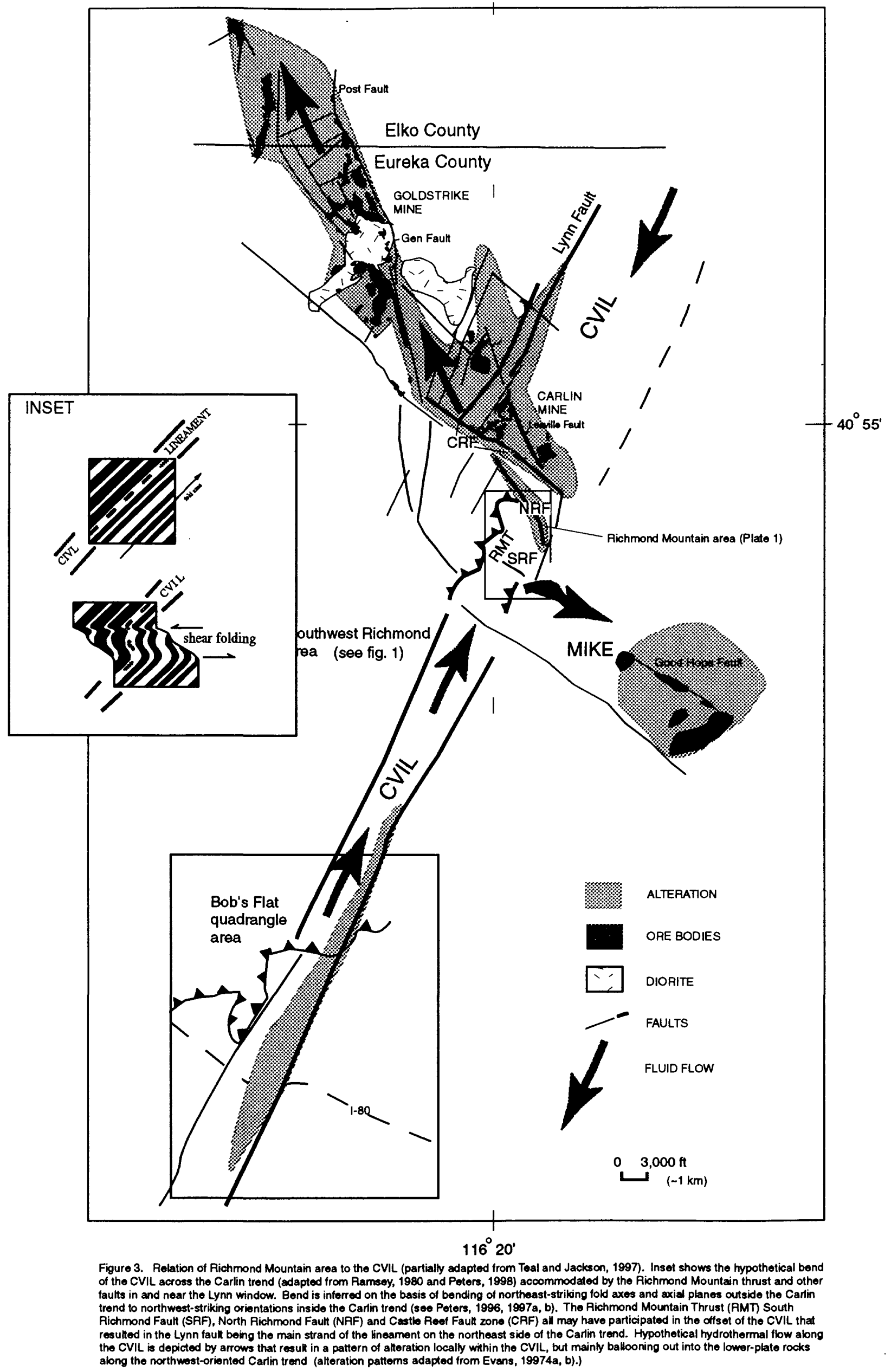


interval of time is consistent with crosscutting relations observed on plate 1 .

Northwest-trending mesoscopic and megascopic fold axes along the Carlin trend were postulated by Evans and Theodore (1978) to be due to Jurassic tectonism. Faults that parallel the fold axial planes of these folds are filled with Jurassic diorite dikes and is thus compatible with synchronous magmatism and tectonism recognized by Ketner and Smith (1982) and by Thorman and others (1991a) in northeast Nevada in the middle Mesozoic. Doming and uplift of the Lynn window is also permissive during this event. Because northwest-striking fabrics post-date northeast-striking fabrics in the Carlin trend area, northeast-trending tectonic fabrics along the CVIL most likely predate the Jurassic.

The Castle Reef fault zone, to the north of the Richmond Mountain area (fig. 3) contains folds that have shallow- westnorthwest-plunging fold axes parallel to the strike of that fault zone. Axial planes of mesoscopic and megascopic folds outside the Castle Reef fault zone are refolded from north-striking to northeast-striking to northwest-striking as they cross the Castle Reef fault zone. The Castle Reef fault zone has been interpreted as a shear fold that refolded these axial planes in the Lynn window in a right lateral sense and may join the northwest-striking Leeville fault (Peters, 1997b).

Jasperoid is common in both the North Richmond fault and in the Castle Reef fault zone to the north and indicates that these fault zones were foci for fluid flow and silicification. If the northeast-striking folds and faults outside the Lynn window are preJurassic, but are oriented north to northwest inside the window, the northeast-striking pre-Jurassic structures in the CVIL also may have been refolded or reoriented in the window (fig. 3). One way to accommodate a reorientation or bend in the CVIL is to invoke the participation of the faults in the Lynn window, such as the Richmond Mountain thrust, the North Richmond fault and the Castle Reef fault zone as illustrated on figure 3.
The northeast-striking Lynn fault (fig. 3) would be equivalent to strands in the CVIL that emerge from the bend and are offset on the northeast side of the Lynn window across the Carlin trend. Fluif may have accompanied or followed this bend and is now manifested as broad zones of alteration, anomalous geochemical zones, such as the North Richmond fault, and as jasperoid along the accommodating faults (fig. 3). Hydrothermal and tectonic events may have been synchronous with or may have post-dated Mesozoic metasomatism along the Richmond Mountain thrust and the Lynn fault zone.

\section{Acknowledgments}

Field work was conducted under access provided by David Groves, Nervmont Exploration Ltd. Many of the basic g?ologic concepts discussed in this report result from discussions with James G. Evans, U.S. Geological Survey, and Newmont Exploration Ltd. personnel, especially Steve Moore, Steve Macmillan, Steve Koehler, David Groves, and Lewis W. Teal. Reviews and edits of the manuscript by James G. Evans and Ted G. Theodore significantly improved the style of presentation.

\section{References cited}

Cowan, D.S., and Bruhn, R.L., 1992, Late Jurassic to early Late Cretaceous geology of the U.S. Cordillera, in Burchfiel. B.C., Lipman, P.W., and Zoback, M.L., eds., The Cordilleran Orogen: Conterminour U.S.: Boulder, Colorado, Geological Society of America, The Geology of North America, v. G-3, p. 169-203.

Evans, J.G., 1974a, Geologic Map of the Rodeo Creek NE Quadrangle, Eureka County, Nevada: U.S. Geological Survey, Geologic Quadrangle Map, GQ-1116, scale 1:24,000.

1974b, Geologic map of the Welches Canyon quadrangle, Eureka County, Nevada: U.S. Geological Survey Geol. Quad. Map GQ-1117, scale 1:24,000 
1980, Geology of the Rodeo Creek NE and Welches Canyon quadrangles, Eureka County, Nevada: U.S. Geological Survey Bulletin 1473, 81 p.

Evans, J.G., and Theodore, T.G., 1978, Deformation of the Roberts Mountains allochthon in north-central Nevada: U.S. Geological Survey Professional Paper $1060,18 \mathrm{p}$.

Henry, C.D., and Boden, D.R., 1998, Eocene magmatism: The heat source for Carlintype gold deposits of northern Nevada: Geology, v. 26, n. 12, p. 1067-1070.

Kerrich, Robert, 1986, Fluid transport in lineaments:

Philosophical Transactions Royal Society London, v. A317, p. 216-251.

Kerrich, Robert, and Kyser, T.K., 1994, The geochemistry and role of fluids in large continental structures: an overview, in Hickman, Stephen, Sibson, Richard, and Bruhn, Ronald, eds., 1994, Proceedings of Workshop LXIII The Mechanical Involvement of Fluids in Faulting, 6 - 10 June, 1993: U.S. Geological Survey Open-File Report 94-228, p. 349-389.

Ketner K.B., and Alpha, A.G., 1992, Mesozoic and Tertiary rocks near Elko, Nevadaevidence for Jurassic to Eocene folding and low-angle faulting: U.S. Geological Survey Bulletin 1988-C, 13 p.

Ketner, K.B., and Smith, J.F., Jr., 1982, MidPaleozoic age of the Roberts thrust unsettled by new data from northern Nevada: Geology, vol. 10, p. 298-303.

Ketner, K.B., Murchey, B.L., Stamm, R.G., and Wardlaw, B.R., 1993, Paleozoic and Mesozoic rocks of Mount Icabod and Dorsey Canyon, Elko County, Nevada-evidence for Post-early Triassic emplacement of the Roberts Mountains and Golconda allochthons: U.S. Geological Survey Bulletin 1988-D, 12 p.

Kuehn, C.A., and Rose, A.W., 1995, Carlin gold deposits, Nevada: Origin in a deep zone of mixing between normally pressured and over pressured fluids: Economic Geology, v. 90, p. 17-36.

Madrid, R.J., 1987, Stratigraphy of the Roberts Mountains allochthon in northcentral Nevada: unpublished Ph.D. dissertation, Stanford University, $332 \mathrm{p}$.
Madrid, R.J., and Bagby, W.C., 1986, Structural alignment of sediment-hosted gold deposits in north-central Nevada: An example of inherited fabrics [abs]: Geological Society of America Abstracts with Programs, v. 18, p. 393.

Madrid, R.J., and Roberts, R. J., 1990, Origins of gold belts in north-central Nevada, in The Geology and Ore Deposits of the Great Basin, Field Trip 15, Guidebook: Geological Society of Nevada, Reno, Nevada, p. 927-939.

Madrid, R.J., Poole, F.G., and Wrucke, C.T., 1992, Rocks of the Antler orogen-The Roberts Mountain allochthor. in Burchfiel, B.C., Lipman, P.W., and Zoback, M.L., eds., The Cordilleran Orogen: Conterminous U.S.: Geological Society of America, The Geology of North America, Volume G-3, p. 28-34.

Merriam, C.W., and Anderson, C.A., 1942, Reconnaissance survey of the Roberts Mountains, Nevada: Geological Society America Bulletin, v. 53, no. 12, F. 16751727.

Miller, D.M., Nilsen, T.H., and Bilodeau, W.L., 1992, Late Cretaceous to early Eocene geologic evolution of the U.S. Cordillera, in Burchfiel, B.C., Lipman, P.W., and Zoback, M.L., eds., The Cordilleran Orogen: Conterminous U.S.: Boulder, Colorado, Geological Society of America, The Geology of North America, v. G-3, p. 205-260.

Peters, S.G., 1996, Definition of the Carlin trend using orientation of fold ares and applications to ore control and zoning in the central Betze orebody, Betze-Post Mine, in Green, Steve ed., Trip B, Structural Geology of the Carlin Trend, Geology and Ore Deposits of the American Cordillera-A Symposium, Field Guide Compendium: Geological Society of Nevada, Reno, Nevada, p. 59-95.

1997a, Structural transect across the southern Carlin trend, Eureka County, Nevada: U.S. Geological Survey OpenFile Report 97-0347, 27 p. 2 sheets, [scale 1:500].

1997b, Structural transect across the central Carlin trend, Eureka County, Nevada: U.S. Geological Survey OpenFile Report 97-55, 40 p., 2 sheets, [scale $1: 6,000]$. 
-1997c, Structural transect across the north-central Carlin trend, Eureka County, Nevada: U.S. Geological Survey OpenFile Report 97-83, 41 p., 6 sheets, [scale 1:500].

1997d, The nature of some upper- and lower-plate rocks near the Roberts Mountains thrust, Carlin trend, in Perry, A.J., and Abbot, E.W., 1997, The Roberts Mountains Thrust, Elko and Eureka Counties, Nevada: Nevada Petroleum Society, 1997 Field Trip Guidebook, Reno, Nevada, p. 35-40.

-1998, Evidence for the Crescent Valley-Independence Lineament, northcentral Nevada, in Tosdal, R.M., ed., Contributions to the Gold Metallogeny of Northern Nevada: U.S. Geological Survey Open-File Report 98-338, p. 106118.

Phillips, J.W., 1986, Hydraulic fracturing effects in the formation of mineral deposits: Transactions Institute Mining and Metallurgy, v. 95, p. B17-24.

Ramsey, J.G., 1980, Shear zone geometry: a review: Journal of Structural Geology, v. 2, no $1 / 2$, p. 83-99.

Roberts, R.J., 1960, Alignment of mining districts in north-central Nevada: U.S. Geological Survey Professional Paper 400B, p. 17-19.

_-1966, Metallogenic provinces and mineral belts in Nevada: Nevada Bureau of Mines Report 13, pt. A, p. 47-72.

Roberts, R.J., Hotz, P.E., Gilluly, J., and Ferguson, H.G., 1958, Paleozoic rocks of north-central Nevada: American Association of Petroleum Geologists Bulletin, v. 42, no. 12, p. 2813-2857.

Saleeby, J.B., and Busby-Spera, C., 1992, Early Mesozoic tectonic evolution of the western U.S. Cordillera, in Burchfiel, B.C., Lipman, P.W., and Zoback, M.L., eds., The Cordilleran Orogen: Conterminous U.S.: Boulder, Colorado, Geological Society of America, The Geology of North America, v. G-3, p. 107168.

Seedorff, Eric, 1991, Magmatism, extension, and ore deposits of Eocene to Holocene age in the Great Basin-mutual effects and preliminary proposed genetic relationships, in Raines, G.L., Lisle, R.E., Schafer, R.W., and Wilkinson, W.H., eds., Geology and Ore Deposits of the Great Basin, Geologic Society of Nevada Symposium Proceedings, Reno/Sparks, Nevada, April, 1990, p.133-178.

Shawe, D.R., 1991, Structurally controlled gold trends imply large gold resources in Nevada, in Raines, G.L., Lisle, R.E., Schafer, R.W., and Wilkinson, W.H., eds., Geology and Ore Deposits of the Great Basin: Geologic Society of Nevada Symposium Proceedings, Reno/Sparks, Nevada, April, 1990, p. 193-212.

Stewart, J.H., and Carlson, J.E., 1976, Geologic map of north-central Neva da: Nevada Bureau of Mines and Geology, Map 50, 1 sheet, scale 1:250,000.

Teal, Lewis, and Branham, Alan, 1997, Geology of the Mike gold-copper deposits, Eureka County, Nevada, in Vikre, Peter, Thompson, T.B., Bettles, K., Christensen, O., and Parrat, R., eds., Carlin-Typ? Gold Deposits Field Conference: Sociaty of Economic Geologists Guidebook Series, vol. 28, p. 257-276.

Teal, Lewis, and Jackson, Mac, 1997, Geologic overview of the Carlin trend gold deposits and descriptions of recent deep discoveries, in Vikre, Peter, Thompson, T.B., Bettles, Keith, Christensen, Odin, and Parrat, Ron. eds., Carlin-Type Gold Deposits Field Conference: Sociaty of Economic Geology Guidebook Series, v. 28, p. 3-37.

Theodore, T.G., Armstrong, A.K., Harris, A.G., Stevens, C.H., and Tosdal, R.M., 1998, Geology of the northern terminus of the Carlin trend, Nevada: links botween crustal shortening during the Late Paleozoic Humboldt orogeny and northeast-striking faults, in Tosdal R. $M^{\wedge}$., ed., Contributions to the gold metallog ny of northern Nevada: U.S. Geological Survey Open-File Report 98-338, p. 69-105.

Thorman, C.H., Ketner, K.B., and Peterson, Fred, 1990, The Elko orogeny-Late Jurassic orogenesis in the Cordilleran miogeocline: Geological Society of America Cordilleran Meeting, Programs with Abstract, v. 22, no. 3, p. 88.

Thorman, C.H., Ketner, K.B., Brooks, W.E., Snee, L.W., and Zimmerman, R.A., 1991a, Late Mesozoic-Cenozoic tectonics in northeastern Nevada, in Raines, G.I., Lisle, R.W., Schafer, R.W., and 
Wilkinson, W.H., eds., Geology and Ore Deposits of the Great Basin, Symposium Proceedings: The Geological Society of Nevada, p. 25-45.

Thorman, C.H., Ketner, K.B., Snoke, A.W., Brooks, W.E., and Mueller, K.J., 1991b, Evidence for the involvement of the Roberts Mountains allochthon in Mesozoic tectonics and its effect on mineral deposit and petroleum accumulation models in northeast Nevada, Field Trip 13, in Buffa, R.H., and Coyner, A.P.., eds., Geology and Ore Deposits of the Great Basin-Field Trip Guidebook Compendium-Great Basin Symposium, April, 1990, Geological Society of Nevada, Reno/Sparks, p. 869905.

Wallace, A. R., 1991, Effect of Late Miocene extension on the exposures of gold deposits in north-central Nevada, in Raines, G.L., Lisle, R.E., Schafer, R.W., and Wilkinson, W.H., eds., Geology and Ore Deposits of the Great Basin: Geologic Society of Nevada Symposium Proceedings, Reno/Sparks, Nevada, April, 1990, p. 179-184. 